\title{
PENGARUH PERLAKUAN PENAMBAHAN EKSTRAK DAN PUREE WORTEL (Daucus carota L.) PADA TEKNOLOGI PRODUKSI CHILI CREAM CHEESE: KAJIAN RENDEMEN, pH, LEMAK, BETAKAROTEN, AKTIVITAS ANTIOKSIDAN DAN SENSORI
}

\author{
THE EFFECT OF ADDITION CARROT EXTRACT AND CARROT PUREE (Daucus carota \\ L.) ON PRODUCTION CHILLI CREAM CHEESE : THE REVIEW OF YIELD, $p H$, FAT, \\ BETACAROTENE, ANTIOXIDANT ACTIVITY AND SENSORY
}

\author{
Armida Oktavia, Choirul Anam, Esti Widowati ${ }^{1}$ \\ ${ }^{1)}$ Ilmu dan Teknologi Pangan, Fakultas Pertanian, Universitas Sebelas Maret, \\ email: solusiprivat@gmail.com
}

\begin{abstract}
The aims of this research was to know one of some Chili Cream Cheese with addition carrot extract and one of some Chili Crem Cheese with addition carrot puree reviewed from sensory, yield, pH, fat, betacarotene and antioxidant activity qualities. The experiment design using Completely Randomized Consentration with one factor. That is carrot extract and carrot puree concentration (7\%; $14 \% 121 \%)$. The selected Chili Cream Cheese with addition carrot extract is Chili Cream Cheese with addition carrot extract $7 \%$ with the best parameters of smell, colour, texture, flavour, aftertaste, spreadable and overall. It has yield

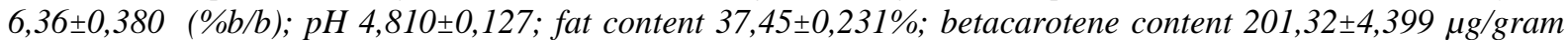
sample and antioxidant activity 2,20 $\pm 0,074 \%$ scavenge of dpph radical/mg sample. The selected Chili Cream Cheese from addition carrot puree is with addition carrot puree $21 \%$. The value of smell, colour and spreadable have the best value but from texture, flavour, aftertaste and overall parameters have number two value. Yield

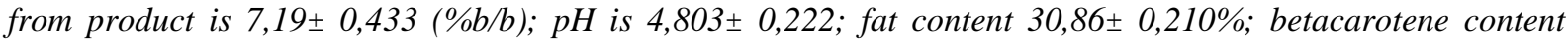
$244,97 \pm 6,728 \mu \mathrm{g} / \mathrm{gram}$ sample and antioxidant activity 4,32 $\pm 0,075 \%$ scavenge of dpph radical/mg sample.
\end{abstract}

Keywords: antioxidant activity, $\beta$-karoten, carrot extract, carrot puree, cream cheese

\section{ABSTRAK}

Tujuan penelitian ini adalah untuk mengetahui pengaruh penambahan konsentrasi dan jenis fortifikan (ekstrak wortel dan puree wortel) terhadap karakteristik fisik ( $\mathrm{pH}$ dan rendemen), kimia (kadar lemak, $\beta$-karoten dan aktivitas antioksidan) dan karakteristik sensori (aroma, warna, tekstur, rasa, aftertaste, daya oles, overall)dari Chili Cream Cheese serta mengetahui karakteristik fisik, kimia dan sensori Chili Cream Cheese dengan perlakuan penambahan wortel yang terpilih. Rancangan percobaan adalah Rancangan Acak Lengkap (RAL) dengan satu faktor yaitu kombinasi perlakuan jenis fortifikan (ekstrak dan puree wortel) dengan penambahan konsentrasinya $(7 \% ; 14 \%$ 21\%). Chili Cream Cheese terpilih dari penambahan ekstrak wortel adalah dengan konsentrasi $7 \%$ dengan penilaian aroma, warna, tekstur, rasa, aftertaste, daya oles dan overall

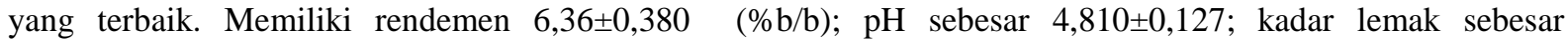
$37,45 \pm 0,231 \%$; kadar $\beta$-karoten sebesar 201,32 $\pm 4,399 \mu \mathrm{g} / \mathrm{gram}$ sampel dan aktivitas antioksidan sebesar 2,20 $\pm 0,074 \%$ penangkapan radikal dpph/gram sampel. Chili Cream Cheese terpilih dari penambahan puree wortel adalah dengan konsentrasi $21 \%$. Penilaian aroma, warna dan daya oles memiliki penilaian yang terbaik, sedangkan dari segi tekstur, rasa, aftertaste dan overall memiliki penilaian terbaik kedua. Nilai rendemen dari

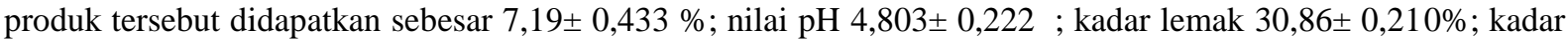
betakaroten $244,97 \pm 6,728 \mu \mathrm{g} / \mathrm{gram}$ sampel; aktivitas antioksidan 4,32 $\pm 0,075 \%$ penangkapan $\mathrm{radikal} \mathrm{dpph} / \mathrm{mg}$ sampel.

Kata Kunci : aktivitas antioksidan, $\beta$-karoten ekstrak wortel, keju krim, puree wortel

\section{PENDAHULUAN}

Cream Cheese merupakan salah satu keju segar (fresh cheese) yangbiasa diaplikasikan sebagai olesan pada roti, pelengkap sandwich, campuran masakan, salad dressing, snack, dips dan sayuran kukus juga pelengkap pada kentang bakar. Senyawa yang bersifat antioksidan dapat meningkatkan peranan produk makanan tersebut untuk kesehatan manusia. Produk Cream Cheese akan menghasilkan pangan fungsional (Silalahi, 2006) jika ditambahkan antioksidan di dalamnya.

Di pasaran telah banyak Cream Cheese yang dikombinasikan dengan ekstrak ataupun puree buah dan herba seperti strawberry, banana, peach, apricot, apple, cinnamons, ginger dll. Akan tetapi, masih sedikit studi yang membahas untuk produk serupa yang 
dikombinasikan dengan ekstrak atau puree dari sejenis sayuran yaitu berupa wortel.

Keutamaan wortel adalah mengandung $\beta$-karoten sebagai antioksidan dan zat anti kankernya dari zat falcarinol.Wortel sebagai sumber fortifikan dalam penelitian ini memiliki kandungan $\beta$-karoten sebesar $3169,75 \mu \mathrm{g} / 100$ gram (USDA, 1994). Wortel memiliki efek perlindungan kesehatan dengan jumlah kandungan $\beta$-karoten tersebut dan antioksidan lain yang terkandung di dalamnya.Selain itu, $\beta$-karoten dapat berfungsi sebagai food colouring sehingga Cream Cheese menjadi berwarna oranye.

Pengolahan ekstrak maupun puree wortel adalah melihat keuntungan sumber fortifikan ini yang dapat membebaskan nutrisi di dalamnya dan mempertahankan warnakarena telah melalui proses blanching dan penghancuran. Proses blanching dan penghancuran diantaranya dapat meningkatkan kemampuan $\beta$-karoten yang ada di dalam wortel untuk diserap tubuh antara 15-30\% (Ningtias, 2008).

\section{METODE PENELITIAN}

\section{Bahan dan Alat}

Bahan utama adalah Wortel Imperator varietas Tawangmangu dengan diameter 3$3,5 \mathrm{~cm}$ dan panjang $21 \mathrm{~cm}$ yang dibeli dari hypermart wilayah Surakarta dan susu segar yang didapat dari KUD Boyolali. Bahan pembantu adalah bakteri Lactococcus lactis FNCC 0086 dari Laboratorium Pusat Studi Pangan dan Gizi (PSPG) Universitas Gajah Mada, de Man Rogossa Sharpe (MRS Broth) (CMO 359 OXOID) dan MRS Agar (LP001 OXOID) didapat dari Laboratorium Biologi Fakultas MIPA Universitas Sebelas Maret, rennet mikrobial (Fromase 50) didapat dari homemade cheese di Depok, Carboxy Metil Cellulosa (CMC), Kalsium Klorida $\left(\mathrm{CaCl}_{2}\right)$, aquades dari toko kimia Agung Jaya wilayah Surakarta. Cabai merah TM 999 dan garam $(\mathrm{NaCl})$ (Refina) dari hypermart wilayah Surakarta.

Alat-alat yang digunakan dalam pembuatan Chili Cream Cheese adalah autoklaf, refrigerator, neraca analitik (Adventure Dhalis), pH meter Eutech Instrumen (Ecoscsan pH 6), vortex (Heidolph reax control), seperangkat alat pengepres, blender (Miyako), juser (Miyako), kompor, panci, termos es, pengaduk, baskom nampan, plastik bening besar, kain blacu, tabung reaksi, Erlenmeyer(Pyrex), jarum oose, magnetic stirrer, spatula, gelas ukur (Pyrex), beaker glass (Pyrex) dan plastik HDPE. Uji sifat fisik dan kimia digunakan alat-alat seperti spektrofotometer UV mini-1240 (Shimadzu), tabung butyrometer (Pyrex), pipet volumetric 17,6 ml (Pyrex), water bath, $\mathrm{pH}$ meter Eutech Instrumen (Ecoscan $\mathrm{pH} 6$ ). Uji sifat sensori digunakan alat berupa borang uji sensori.

\section{Tahapan Penelitian}

Penelitian ini terdiri dari penelitian pendahuluan dan penelitian utama. Pada penelitian pendahuluan ditentukan proporsi setiap bahan-bahan yang diperlukan serta modifikasi penambahan ekstrak wortel dan puree wortel masing-masing sebesar 2\%; $3 \%$; $4 \% ; 7 \% ; 14 \% ; 21 \%$. Proporsi jumlah penambahan $\mathrm{CaCl}_{2}$, garam, rennet, kultur dan susu serta ekstrak dan puree wortel yang dipilih merupakan formulasi yang pada range tersebut terdapat beberapa hasil Chili Cream Cheese yang firm, rasa dan aroma yang enak, dan bisa dioles seperti ditunjukkan pada Tabel 1. Pembuatan sampelini dilakukan dengan beberapa tahap diantaranya : terlebih dahulu membuat (1) bulk starter atau starter kerja (Gandhi, 2006), (2) membuat krim susu (Haryanto,2012) (3) membuat ekstrak wortel (Zubaidah dkk., 2005) dengan modifikasi (Asgar dan Musaddad, 2006), (4) membuat puree wortel (Suraningsih, 2000) dengan modifikasi (Asgar dan Musaddad, 2006) dan (Mutiara, 2000), (5) membuat cabai giling, (6) membuat Chilli Cream Cheese dengan dilakukan penambahan ekstrak dan puree wortel (Mulyani dkk., 2009) dengan modifikasi (Haryanto, 2012), (Kosikowski, 2007) dan (Hill, 2008).

Pada penelitian pendahuluan telah diperoleh formulasi Chili Cream Cheese with Carrot yang akan digunakan pada penelitian utama. Proses pembuatan Chilli Cream Cheese with Carrot dapat dilihat pada Gambar 1.

1) Pengujian Organoleptik dengan Multiple Comparison Test (Kartika, 1988) 
Pengujian sampel keju dilakukan oleh panelis yang telah diseleksi kesukaannya terhadap produk berbahan susu, terutama keju dan memiliki intensitas konsumsi keju sebanyak satu kali atau lebih dalam 1 minggu. Dengan demikian, data yang diperoleh dapat diperoleh secara statistik, yaitu dengan ANOVA, karena data interval dipertimbangkan sebagai data kuantitatif sejati.

2) Penentuan Rendemen Perbandingan (AOAC, 1990)

Penentuan rendemen dilakukan dengan caramemperhitungkan hasil perolehan keju dibandingkan 100 gram susu mentah.

3) Penentuan (nilai $\mathrm{pH}$ ) Metode Potensiometri (AOAC, 1970)

Pada penentuan derajat keasaman, dilakukan dengan mencelupkan elektroda pada sampel dan mencatat angka yang konstan.

4) Pengukuran Kadar Lemak Metode Gerber (FAO,2005)

Pada pengukuran kadar lemak, dipersiapkan tabung butyrometer dengan kapasitas kadar lemak kurang lebih $70 \%$. Sampel dimasukkan ke dalam tabung tersebut sebanyak 3 gram dan ditambahkan dengan $0,1 \quad \mathrm{~N} \quad \mathrm{H}_{2} \mathrm{SO}_{4}$. Kemudian ditambahkan juga dengan $1 \mathrm{~mL}$ isoamil alkohol. Kemudian tabung butyrometer tersebut ditutup dan dikocok dengan hati-hati hingga merata.Tabung dimasukkan dalam waterbath dengan suhu $45^{\circ} \mathrm{C}$.Tabung disentrifuge dengan alat sentrifuge pada $1100-1200$ rpm selama \pm 5 menit pada suhu yang direkomendasikan $45^{\circ}$ C.Kadar lemak dibaca pada skala tabung butyrometer.

5) Pengukuran Kadar $\beta$-karoten Metode Spektrofotometri (Price, 1992)

a) Pembuatan Larutan Standar $\beta$-karoten

Sebanyak 50,5 mg potassium dikromat diencerkan dengan aquadest pada labu ukur $100 \mathrm{~mL}$.

b) Pembuatan Kurva Standar $\beta$-karoten

Pembuatan deret standar $\beta$-karoten 0; $0,01 \mathrm{ppm} ; 0,02 \mathrm{ppm} ; 0,03 \mathrm{ppm} ; 0,04$ ppm; 0,05 ppm dilakukan dengan cara larutan standar $\beta$-karoten505 ppm dipipet sebanyak $0 \mathrm{~mL} ; 2 \mathrm{~mL} ; 4 \mathrm{~mL}$;
$6 \mathrm{~mL} ; 8 \mathrm{~mL}$ dan $10 \mathrm{~mL}$ dan ditambahkan dengan aquades masing -masing $10 \mathrm{~mL} ; 8 \mathrm{~mL} ; 6 \mathrm{~mL} ; 4 \mathrm{~mL} ; 2 \mathrm{~mL}$ dan $0 \mathrm{~mL}$

c) Pembacaaan Kurva Standar $\beta$-karoten Deret standar tersebut masing-masing ditera absorbansinya pada $450 \mathrm{~nm}$ dengan menggunakan spektrofotometer. Sebagai blanko digunakan aquadest.

d) Persiapan Sampel Keju

Sebanyak 1,850 gram sampel keju ditambahkan 2,5 $\mathrm{mL}$ etanol $96 \%$ dan divortex selama \pm 1 menist kemudian ditambahkan $10 \mathrm{~mL}$ Petroleum Eter dan ditutup, kemudian divortex kembali selama 10 menit. Larutan yang berwarna kuning dipisahkan dengan diambil 2 mL.kemudian larutan kuning tersebut ditambabkan 3 mL Petroleum Eter dan divortex.

e) Pengukuran Absorbansi Sampel Keju $5 \mathrm{ml}$ larutan tersebut masing-masing ditera absorbansinya dengan Spektrofotometer pada $450 \mathrm{~nm}$ dengan blanko Petroleum Eter.

6) Pengukuran Aktivitas Antioksidan Metode Penangkapan Radikal DPPH (Subagio et al., 2002)

a) Pembuatan Larutan DPPH

Kristal DPPH ditimbang sebanyak $9,858 \quad$ mgram $=0,009858$ gram $/ 50 \mathrm{~mL}=0,0001972$

$\mathrm{g} / \mathrm{mL}=0,001972 \quad \mathrm{ppm}$ kemudian dilarutkan dalam metanol dengan labu ukur tepat $50 \mathrm{~mL}$ sehingga kadarnya 0,002 ppm yaitu $0,5 \mathrm{mM}$.

b) Pengenceran Sampel Keju

0,1 gram sampel keju diencerkan sampai $10 \mathrm{~mL}$ metanol sehingga kadarnya menjadi 0,01 ppm kemudian diambil $5 \mathrm{~mL}$ dan disentrifuge selama 13 menit. Dari larutan itu diambil kembali $1 \mathrm{~mL}$ dan ditambahkan 3,5 mL metanol dan juga ditambahkan 0,5 mL DPPH 0,5 mM.

c) Pengukuran Absorbansi Larutan Kontrol DPPH

Spektra absorbansi DPPH diukur pada panjang gelombang $(\lambda)$ 400-700 $\mathrm{nm}$. Larutan blanko yang digunakan adalah methanol.Pencatatan dilakukan 


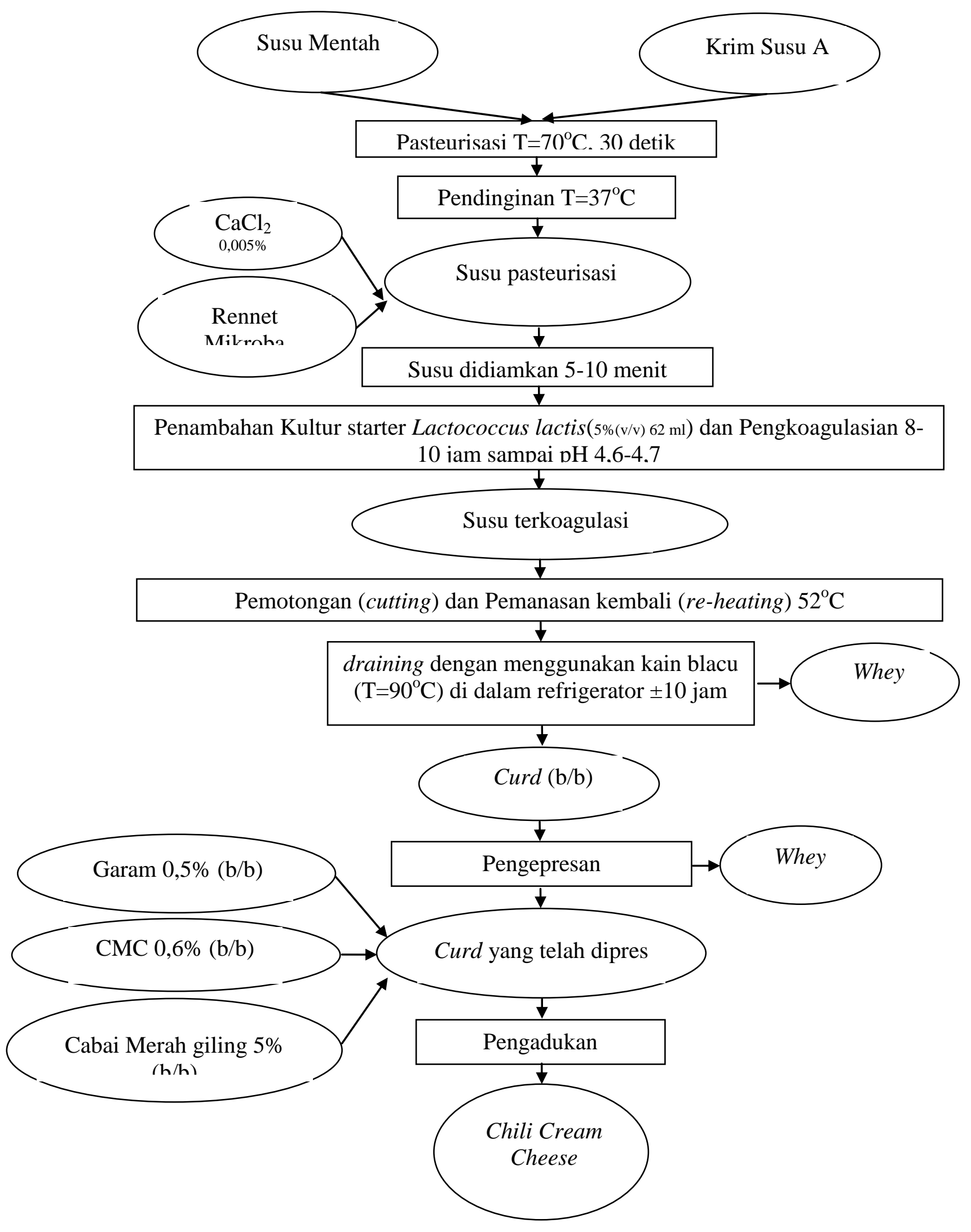

Gambar 1.Tahap Pembuatan Chili Cream Cheese with Carrot (Mulyani et al., 2009) dengan modifikasi 
terhadap absorbansi pada panjang gelombang $517 \mathrm{~nm}$. Untuk pengukuran absorbansi kontrol DPPH dilakukan dengan terlebih dahulu 4,5 $\mathrm{ml}$ methanol ditambahkan $0,5 \mathrm{ml}$ DPPH $0,5 \mathrm{mM}$ lalu divortex selama \pm 2 menit dan disimpan dalam ruang gelap selama 30 menit. Kemudian ditera 517 nm.

d) Pengukuran Absorbansi Sampel

Pada pengukuran sampel, larutan 0,001 ppm pada pengenceran sampel keju, diambil kembali $1 \mathrm{~mL}$ dan ditambahkan 3,5 mL methanol, juga ditambahkan larutan DPPH 0,5 mM sebanyak $5 \mathrm{~mL}$ kemudian divortex \pm 2 menit dan disimpan dalam ruang gelap selama 30 menit yang kemudian ditera $517 \mathrm{~nm}$.

\section{HASIL DAN PEMBAHASAN}

\section{Karakteristik Sensoris ChiliCream Cheese dengan Penambahan Ekstrak dan Puree Wortel}

\section{Aroma}

Panelis menilai terbaik dibandingkan kontrol pada sampel dengan penambahan ekstrak wortel adalah dngan penambahan ekstrak wortel $7 \%$, sedangkan penilaian terbaik dari Chili Cream Cheese dengan penambahan puree wortel adalah dengan penambahan puree wortel $21 \%$ (Tabel 1). Hal ini dikarenakan dengan penambahan puree wortel $21 \%$, penilaian panelis dengan penambahan ekstrak wortel yang lebih tinggi, kandungan air lebih banyak sehingga aroma volatil sulit untuk menguap. Dengan penambahan puree wortel. Aroma yang terdeteksi adalah aroma yang menonjol asam dari asam laktat, aroma cabai dan aroma dari daging umbi wortel.

\section{Warna}

Panelis menilai tertinggi dibandingkan dengan kontrol pada sampel dengan penambahan ekstrak wortel adalah dengan penambahan ekstrak wortel $7 \%$, sedangkan penilaian terbaik dari Chili Cream Cheese dengan penambahan puree wortel adalalh dengan penambahan puree wortel $21 \%$ (Tabel 1).

\section{Tekstur}

Panelis menilai tertinggi dibandingkan dengan kontrol pada sampel dengn penambahan ekstrak wortel adalah dengan penambahan ekstrak wortel $7 \%$, sedangkan penilaian terbaik dari Chili Cream Cheese dengan penambahan puree wortel adalah dengan penambahan puree wortel $14 \%$ (Tabel 1).

\section{Rasa}

Panelis menilai tertinggi dibandingkan dengan kontrol pada sampel dengan penambahan ekstrakwortel adalah dengan penambahan ekstrak wortel 7\%, sedangkan penilaian terbaik dari Chili Cream Cheese dengan penambahan puree wortel yang terbaik adalah dari penambahan puree wortel $14 \%$.

\section{Aftertaste}

Panelis menilai tertinggi dibandingkan dengan kontrol pada sampel dengan penambahan ekstrak wortel adalah dengan penambahan ekstrak wortel $7 \%$, sedangkan penilaian terbaik dari Chili Cream Cheese dengan penambahan puree wortel yang terbaik adalah dari penambahan puree wortel $21 \%$.

\section{Daya Oles}

Panelis menilai tertinggi dibandingkan dengan kontrol pada sampel dengan penambahan ekstrak wortel $7 \%$, sedangkan penilaian terbaik dari Chili Cream Cheese dengan penambahan puree wortel yang terbaik adalah dari penambahan puree wortel $14 \%$.

\section{Overall}

Secara keseluruhan, penilaian secara overall, dari sampel Chili Cream Cheese dengan penambahan ekstrak wortel, dengan penambahan konsentrasi $7 \%$ adalah penilaian panelis yang terbaik.Semakin tinggi penambahan ekstrak wortel, maka penilaian panelis semakin menurun. Hal itu disebabkan dari aroma, warna, tekstur, rasa, aftertaste dan daya oles didapatkan kondisi Chili Cream Cheese dengan penambahan ekstrak 
Tabel 1. Pengaruh Penambahan EkstrakWortel dan Puree Wortel terhadap Sifat Sensori Chili Cream Cheese

\begin{tabular}{lccccccc}
\hline \multirow{2}{*}{ Perlakuan Sampel } & \multicolumn{5}{c}{ Parameter } \\
\cline { 2 - 7 } & Aroma & Warna & Tekstur & Rasa & Aftertaste & Daya oles & Overall \\
\hline Ekstrak Wortel 7\% & $4,13 \pm 1,11^{\mathrm{a}}$ & $4,40 \pm 1,13^{\mathrm{ab}}$ & $4,20 \pm 1,16^{\mathrm{ab}}$ & $3,90 \pm 1,16^{\text {abc }}$ & $4,20 \pm 1,06^{\mathrm{a}}$ & $4,20 \pm 1,10^{\mathrm{ab}}$ & $4,40 \pm 0,86^{\mathrm{ab}}$ \\
Ekstrak Wortel 14\% & $4,00 \pm 1,42^{\mathrm{a}}$ & $4,27 \pm 1,41^{\mathrm{ab}}$ & $3,60 \pm 1,28^{\mathrm{a}}$ & $3,33 \pm 1,37^{\mathrm{a}}$ & $3,63 \pm 1,52^{\mathrm{a}}$ & $3,67 \pm 1,30^{\mathrm{a}}$ & $3,90 \pm 1,10^{\mathrm{a}}$ \\
EkstrakWortel 21\% & $4,03 \pm 1,27^{\mathrm{a}}$ & $3,93 \pm 1,49^{\mathrm{a}}$ & $3,53 \pm 0,87^{\mathrm{a}}$ & $3,43 \pm 1,28^{\mathrm{ab}}$ & $3,73 \pm 1,48^{\mathrm{a}}$ & $3,87 \pm 1,76^{\mathrm{a}}$ & $3,93 \pm 1,26^{\mathrm{a}}$ \\
Puree Wortel 7\% & $4,03 \pm 1,07^{\mathrm{a}}$ & $4,00 \pm 0,79^{\mathrm{ab}}$ & $3,93 \pm 1,08^{\text {ab }}$ & $3,567 \pm 1,17^{\mathrm{ab}}$ & $3,77 \pm 1,07^{\mathrm{a}}$ & $4,17 \pm 0,88^{\mathrm{ab}}$ & $4,23 \pm 0,86^{\mathrm{ab}}$ \\
Puree Wortel 14\% & $4,07 \pm 1,11^{\mathrm{a}}$ & $4,367 \pm 0,62^{\mathrm{ab}}$ & $4,37 \pm 1,27^{\mathrm{b}}$ & $4,37 \pm 1,27^{\mathrm{c}}$ & $4,17 \pm 1,23^{\mathrm{a}}$ & $4,27 \pm 1,17^{\mathrm{ab}}$ & $4,67 \pm 0,84^{\mathrm{b}}$ \\
Puree Wortel 21\% & $4,17 \pm 1,18^{\mathrm{a}}$ & $4,60 \pm 0,97^{\mathrm{b}}$ & $4,23 \pm 1,07^{\text {ab }}$ & $4,13 \pm 1,36^{\mathrm{bc}}$ & $4,17 \pm 1,21^{\mathrm{a}}$ & $4,63 \pm 0,90^{\mathrm{bc}}$ & $4,63 \pm 0,81^{\mathrm{b}}$ \\
\hline
\end{tabular}

wortel $7 \%$ yang lebih baik daripada yang lain.

Pada Tabel 1 juga didapatkan penilaian secara overall dari sampel Chili Cream Cheese dengan penambahan puree wortel $14 \%$ adalah sampel yang mendapatkan penilaian panelis tertinggi dari keseluruhan atribut sensori dibandingkan sampel dengan penambahan puree wortel $21 \%$. Hal ini disebabkan dari aroma, warna, tekstur, rasa, aftertaste dan daya oles dari Chili Cream Cheese dengan penambahan tersebut yang lebih baik dibandingkan dengan sampel dengan penambahan puree wortel $14 \%$ dan $21 \%$.

\section{Karakteristik Fisik Chili Cream Cheese dengan Penambahan Ekstrak dan Puree Wortel}

\section{Rendemen}

Berdasarkan rendemen dari perlakuan penambahan ekstrak dan puree wortel, maka didapatkan nilai rendemen tertinggi masingmasing adalah dengan penambahan ekstrak wortel $21 \%$ dan Chili Cream Cheese dengan penambahan puree wortel $21 \%$. Hal tersebut disebabkan penambahan ekstrak dan pureewortel dilakukan di akhir pembuatan keju, sehingga tidak lagi mengalami perlakuan apapun (Tabel 2).

\section{Derajat Keasaman}

Pada Tabel 2 pemilihan Chili Cream Cheese terbaik dari sifat fisik berupa derajat keasaman dengan penambahan ekstrak wortel, didapatkan nilai $\mathrm{pH}$ yang paling sesuai dengan penelitian tersebut adalah Chili Cream Cheese dengan penambahan ekstrak wortel $7 \%$. Hal ini disebabkan dengan nilai $\mathrm{pH}$ yang semakin tinggi dari 4,8 menyebabkan tekstur produk menjadi lebih encer (Lucey, 2003).

Pemilihan Chili Cream Cheese terbaik dari penambahan puree wortel, didapatkan nilai $\mathrm{pH}$ yang paling sesuai dengan beberapa penelitian dan didapatkan tekstur produk yang lebih baik adalah Chili Cream Cheese dengan penambahan puree wortel $7 \%$ yang sesuai dengan penelitian Poursharif et al. (2012), yang menyebutkan $4,74 \pm 0,03$. Seperti juga menurut Lucey (2003), bahwa nilai $\mathrm{pH}$ harus antara 4,6-4,7 menurut Davis (1982) adalah 4,7, menurut Elenbogen et al. (1968), nilai $\mathrm{pH}$ Cream Cheese adalah 4,6-4,8. Menurut Geng, Ipsen dan Liot (2008) adalah 4,76, menurut USDA (1994), nilai $\mathrm{pH}$ antara 4,4-4,9. Dari beberapa penelitian diatas, pemilihan Cream Cheese terbaik dengan nilai pH 4,74 sudah sangat sesuai dengan ketiga penelitian pendukung tersebut.

\section{Karakteristik Kimia Chili Cream Cheese dengan Penambahan Ekstrak dan Puree Wortel}

\section{Lemak}

Sifat kimia berupa kadar lemak, didapatkan kadar lemak terbaik dari penambahan ekstrak owrtel adalah dari Chili Cream Cheese dengan penambahan ekstrak wortel $7 \%$. Sedangkan kadar lemak terbaik 
Tabel 2. Pengaruh Penambahan Ekstrak Wortel dan Puree Wortel terhadap Sifat Fisik Chili Cream Cheese

\begin{tabular}{cccc}
\hline Jenis Fortifikan & Konsentrasi $(\%)$ & Rendemen & Derajat Keasaman \\
\hline \multirow{3}{*}{ Ekstrak Wortel } & 7 & $6,36 \pm 0,380^{\mathrm{ab}}$ & $4,81 \pm 0,127^{\mathrm{a}}$ \\
& 14 & $6,78 \pm 0,408^{\mathrm{bc}}$ & $4,84 \pm 0,108^{\mathrm{a}}$ \\
& 21 & $7,19 \pm 0,433^{\mathrm{c}}$ & $4,87 \pm 0,111^{\mathrm{a}}$ \\
\hline \multirow{2}{*}{ Puree Wortel } & 7 & $6,36 \pm 0,383^{\mathrm{ab}}$ & $4,75 \pm 0,263^{\mathrm{a}}$ \\
& 14 & $6,78 \pm 0,408^{\mathrm{bc}}$ & $4,75 \pm 0,251^{\mathrm{a}}$ \\
& 21 & $7,19 \pm 0,433^{\mathrm{c}}$ & $4,80 \pm 0,222^{\mathrm{a}}$ \\
\hline
\end{tabular}

dari Chili Cream Cheese dengan penambahan puree wortel, didapatkan dari konsentrasi penambahan $7 \%$. Sampel ini sesuai dengan penelitian Puhan et al. (1994), bahwa Cream Cheese double fat memiliki kadar lemak 30\%. CODEX STAN C-31 1973 ataupun USDA (1994) memberikan batasan kadar minimal lemak Cream Cheese adalah 33\%. Maka dengan jumlah lemak yang semakin tinggi adalah semakin baik.

Pada Chili Cream Cheese dengan penambahan ekstrak wortel $14 \%$ bias digolongkan ke dalam Cream cheese with Other Food type II, Class A. Chili Cream Cheese dengan penambahan ekstrak wortel $21 \%$ dapat digolongkan ke dalam salah satu Cream Cheese double fat seperti pendapat Puhan et al. (1994) dan juga dapat digolongkan Cream Cheese with Other Food type II, Class A karena kadar lemaknya di atas $27 \%$ dan dapat digolongkan pada jenis Neufchatel Cheese with Other Food type IV(Tabel 2).

\section{Betakaroten}

Sampel yang memiliki kadar betakaroten terbaik dari penambahan jenis fortifikan ekstrak wortel adalah ekstrak wortel $21 \%$. Hal ini dikarenakan dengan semakin tinggi penambahan ekstrak wortel, betakaroten sebagai senyawa fungsional yang terdapat pada Chili Cream Cheese. Hal yang sama juga terjadi pada penambahan puree wortel. Sampel dengan kadar betakaroten terbaik adalah dari penambahan puree wortel $21 \%$ (Tabel 2).

\section{Aktivitas Antioksidan}

Sampel yang memiliki aktivitas antioksidan terbaik dari penambahan ekstrak wortel adalah dari penambahan ekstrak wortel $21 \%$, sedangkan dengan

Penambahan puree wortel adalah dari penambahan puree wortel $21 \%$ (Tabel 2). Hal ini dikarenakan ekstrak maupun puree wortel memiliki kandungan antioksidan berupa antioksidan di dalam wortel diantaranya terdapat peranan dari betakaroten, alfa karoten, xantofil, sedikit asam askorbat (Paiva dan Russell, 1999) polifenol, flavonoid, provitamin A (Munawwaroh, 2013) serta asam fenolat, asam tiglik, shogaol, geraniol seperti menurut (Dalimartha, 2008) yang aktivitasnya dapat dideteksi dengan metode penangkapan radikal dpph (1,1-Diphenil-2picrylhidrazine). Cream Cheese diantaranya adalah mengandung biotin atau vitamin B12 (Apraidji, 2007). Sedangkan antioksidan komplemen dari betakaroten yang didapatkan dari cabai merah dengan konsentrasi sama pada setiap sampel, mengandung vitamin B1, B2, B6 dan juga sumber antioksidan yang cukup besar dari vitamin C (Andrianto, 2004). Sehingga aktivitas antioksidan yang semula kurang terdapat di dalam Cream Cheese, menjadi bertambah nilainya.

Pada Tabel 3, Chili Cream Cheese dengan penambahan ekstrak wortel $7 \%$ merupakan sampel yang paling unggul dari segi sensori dari penambahan jenis fortifikan ekstrak wortel. Dari segi fisik berupa derajat keasaman dan kadar lemak, sampel dengan penambahan tersebut juga lebih unggul. Dari 
Tabel 3. Pengaruh Penambahan Ekstrak Wortel dan Puree Wortel terhadap Sifat Kimia Chili Cream Cheese

\begin{tabular}{ccccc}
\hline $\begin{array}{c}\text { Jenis } \\
\text { Fortifikan }\end{array}$ & $\begin{array}{c}\text { Konsentrasi } \\
(\%)\end{array}$ & Kadar Lemak $^{\text {Kadar } \beta \text {-karoten }}$ & $\begin{array}{c}\text { Aktivitas } \\
\text { Antioksidan }\end{array}$ \\
\hline \multirow{2}{*}{ Ekstrak } & 7 & $37,45 \pm 0,231^{\mathrm{a}}$ & $201,32 \pm 4,399^{\mathrm{a}}$ & $2,20 \pm 0,074^{\mathrm{b}}$ \\
Wortel & 14 & $34,76 \pm 0,415^{\mathrm{b}}$ & $203,63 \pm 12,641^{\mathrm{a}}$ & $2,98 \pm 0,045^{\mathrm{b}}$ \\
& 21 & $30,07 \pm 0,272^{\mathrm{c}}$ & $271,98 \pm 10,212^{\mathrm{b}}$ & $3,61 \pm 0,031^{\mathrm{c}}$ \\
\hline \multirow{2}{*}{ Puree Wortel } & 7 & $38,21 \pm 0,228^{\mathrm{a}}$ & $156,75 \pm 7,342^{\mathrm{a}}$ & $3,04 \pm 0,036^{\mathrm{b}}$ \\
& 14 & $35,01 \pm 0,100^{\mathrm{b}}$ & $184,23 \pm 1,385^{\mathrm{b}}$ & $3,37 \pm 0,089^{\mathrm{c}}$ \\
& 21 & $30,86 \pm 0,210^{\mathrm{c}}$ & $244,97 \pm 6,728^{\mathrm{c}}$ & $4,32 \pm 0,075^{\mathrm{d}}$ \\
\hline
\end{tabular}

Tabel 4. Matriks Pemilihan Chilli Cream Cheese berdasarkan Karakteristik Sensori, Fisik dan Kimia

\begin{tabular}{|c|c|c|c|c|c|c|c|}
\hline & \multirow{3}{*}{ Parameter } & \multicolumn{6}{|c|}{ Perlakuan Sampel } \\
\hline & & \multicolumn{3}{|c|}{ Konsentrasi Ekstrak Wortel } & \multicolumn{3}{|c|}{ Konsentrasi Puree Wortel } \\
\hline & & $7 \%$ & $14 \%$ & $21 \%$ & $7 \%$ & $14 \%$ & $21 \%$ \\
\hline \multicolumn{8}{|c|}{ 1. Karakteristik Sensori } \\
\hline a) & Aroma & $4,13 \pm 1,11^{2}$ & $4,00 \pm 1,41 \mathrm{a}$ & $4,03 \pm 1,27^{a}$ & $4,03 \pm 1,07^{\mathrm{a}}$ & $4,07 \pm 1,11 \mathrm{a}$ & $4,17 \pm 1,18^{2}$ \\
\hline b) & Wama & $4,40 \pm 1,13 \mathrm{sb}$ & $4,27 \pm 1,41$ ab & $3,93 \pm 1,48 \mathbf{a}$ & $4,00 \pm 0,79^{a b}$ & $4,367 \pm 0,62^{a b}$ & $4,60 \pm 0,97^{\mathrm{b}}$ \\
\hline c) & Tekstur & $4,20 \pm 1,16^{\mathrm{ab}}$ & $3,60 \pm 1,28^{a}$ & $3,53 \pm 0,87 \mathbf{a}$ & $3,93 \pm 1,08 \mathrm{ab}$ & $4,37 \pm 1,27^{\mathrm{b}}$ & $4,23 \pm 1,07$ ab \\
\hline d) & Rasa & $3,90+1,16^{\mathrm{abc}}$ & $3,33 \pm 1,377^{a}$ & $3,43 \pm 1,28^{\mathrm{ab}}$ & $3,567 \pm 1,17^{a b}$ & $4,37 \pm 1,27 \mathrm{c}$ & $4,13 \pm 1,36^{b c}$ \\
\hline e) & Aftertaste & $4,20 \pm 1,06^{a}$ & $3,63 \pm 1,52 \mathrm{a}$ & $3,73 \pm 1,48^{\mathrm{a}}$ & $3,77 \pm 1,07^{\mathrm{a}}$ & $4,17 \pm 1,23^{2}$ & $4,17 \pm 1,21^{\mathrm{a}}$ \\
\hline f) & Daya Oles & $4,20 \pm 1,10^{\mathrm{ab}}$ & $3,67 \pm 1,30^{2}$ & $3,87 \pm 1,756^{\mathrm{a}}$ & $4,17 \pm 0,87^{a b}$ & $4,27 \pm 1.17^{\text {ab }}$ & $4,63 \pm 0,89 \mathrm{bc}$ \\
\hline g) & Overall & $4,40 \pm 0,86^{\mathrm{ab}}$ & $3,90 \pm 1,09 \mathrm{a}$ & $3,93 \pm 1,26^{\mathrm{a}}$ & $4,23 \pm 0,86^{\mathrm{ab}}$ & $4,67 \pm 0,84^{b}$ & $4,63 \pm 0,81^{b}$ \\
\hline \multicolumn{8}{|c|}{ 2. Karakteristik Fisik } \\
\hline a) & Rendemen & $6,36 \pm 0,380=$ & $6,78 \pm 0,41^{\mathrm{bc}}$ & $7,19 \pm 0,43^{c}$ & $6,36 \pm 0,38^{\mathrm{ab}}$ & $6,78 \pm 0,41^{b c}$ & $7,19 \pm 0,43^{c}$ \\
\hline b) & Nilai pH & $4,81 \pm 0,13^{a}$ & $4,84 \pm 0,11^{\mathbf{a}}$ & $4,87 \pm 0,11^{\mathrm{a}}$ & $4,745 \pm 0,26^{2}$ & $4,750 \pm 0,25^{2}$ & $4,80=0,22^{3}$ \\
\hline \multicolumn{8}{|c|}{ 3. Karakteristik Kimia } \\
\hline a) & Kadar Lemak & $37,45 \pm 0,23^{\mathrm{a}}$ & $34,76 \pm 0,42^{\mathrm{b}}$ & $30,07 \pm 0,27^{\circ}{ }_{\mathrm{A}}$ & $38,21 \pm 0,23^{a}$ & $35,01 \pm 0,10^{b}$ & $30,86 \pm 0,21^{\mathrm{c}}$ \\
\hline b) & Kadar $\beta$-karoten & $201,32 \pm 4,40^{2}$ & $203,63 \pm 12,64^{a}$ & $271,98 \pm 10,21^{\mathrm{b}}$ & $156,75 \pm 7,34^{a}$ & $184,23 \pm 1,39^{b}$ & $244,97 \pm 6,73^{c}$ \\
\hline \multirow[t]{2}{*}{ c) } & Aktivitas & & & & & & \\
\hline & Antioksidan & $2,20 \pm 0,07^{\mathrm{a}}$ & $2,98 \pm 0,05^{\mathrm{a}}$ & $3,6 \mathrm{l} \pm 0,03^{\mathrm{b}}$ & $3,04 \pm 0,04^{\mathbf{a}}$ & $3,369 \pm 0,09^{b}$ & $4,32 \pm 0,08^{c}$ \\
\hline
\end{tabular}

segi sensori dipilih Chili Cream Cheese dengan penambahan ekstrak wortel $7 \%$ dikarenakan sampel tersebut memiliki keunggulan dibandingkan sampel dengan penambahan ekstrak wortel lain. Derajat keasaman dari Chili Cream Cheese dengan penambahan ekstrak wortel $7 \%$ didapatkan penilaian yang paling mendekati kontrol, yaitu dengan nilai $\mathrm{pH} 4,810 \pm 0,127$. Kadar lemak dari Chili Cream Cheese dengan penambahan tersebut memiliki kadar lemak yang paling tinggi dibandingkan sampel dengan penambahan ekstrak wortel lain.

\section{Penentuan Chilli Cream Cheese with Carrot}

\section{Terpilih}

Dari segi statistic (Tabel 4), penilaian secara sensori, mengarah pada penilaian panelis terbaik adalah dengan konsentrasi penambahan puree wortel $14 \%$. Akan tetapi, nilai rendemen sebesar $7,19 \pm 0,433$ adalah merupakan penilaian rendemen yang tertinggi. Sifat lainnya yaitu kadar betakaroten dan aktivitas antioksidan menempatkan sampel Chili Cream Cheese dengan penambahan puree wortel $21 \%$ pada posisi unggul, karena dengan kadar tertinggi dan memiliki perbedaan signifikan dibandingkan dengan yang lain. Dari segi keunggulan sensori dengan konsentrasi yang lebih rendah, sampel dengan penambahan puree wortel $14 \%$ adalah sampel yang terbaik. Oleh karena alasan tidak berbeda signifikan $(\mathrm{p}>0,05)$ secara sensori dengan sampel penambahan puree wortel $21 \%$ dan dengan penilaian panelis yang memperoleh angka $>4$ memiliki arti "sama dengan 
kontrol", maka puree wortel $21 \%$ patut dipertimbangkan. Kelebihan yang mengungguli, dengan kualitas sensori yang tidak berbeda signifikan $(p>0,05)$ dengan sampel dengan penambahan puree wortel $14 \%$, nilai tambah yang didapatkan adalah lebih tinggi. Dari sisi rendemen, kadar betakaroten dan aktivitas antioksidan, sampel dengan penambahan puree wortel $21 \%$ memiliki perbedaan signifikan $(\mathrm{p}<0,05)$ dibandingkan sampel dengan penambahan puree wortel $14 \%$.

\section{KESIMPULAN}

1. Kadar betakaroten dari Chili Cream Cheese dengan perlakuan penambahan ekstrak wortel $7 \%$; $14 \%$ dan $21 \%$ adalah berturut-turut 201,32 $\pm 4,399$; $203,63 \pm 12,641 ; 271,98 \pm 10,212 \mu \mathrm{g} / \mathrm{gram}$ sampel. sedangkan kadar betakaroten dari Chili Cream Cheese dengan perlakuan penambahan puree wortel $7 \% ; 14 \%$ dan $21 \%$ adalah berturut-turut $156,75 \pm 7,342$; $184,23 \pm 1,39 ; \quad 244,97 \pm 6,728 \mu \mathrm{g} / \mathrm{gram}$ sampel. Aktivitas antioksidan dari Chili Cream Cheese dengan perlakuan penambahan ekstrak wortel $7 \% ; 14 \%$ dan $21 \%$ adalah berturut-turut $2,20 \pm 0,074 ; 2,98 \pm 0,045 ; \quad 3,61 \pm 0,031 \%$ penangkapan radikal $\mathrm{dpph} / \mathrm{mg}$ sampel, sedangkan aktivitas antioksidan dari Chili Cream Cheese dengan perlakuan penambahan puree wortel 7\%; 145 dan $21 \%$ berturut-turut adalah $3,04 \pm 0,036$; $3,369 \pm 0,089 ; 4,32 \pm 0,075 \%$ penangkapan radikal dpph/mg sampel.

2. Pengaruh penambahan masing-masing ekstrak wortel ataupun puree wortel dengan konsentrasi berbeda, tidak berpengaruh terhadap $\mathrm{pH}$, sensori (aroma, aftertaste), tetapi berpengaruh terhadap peningkatan rendemen, kadar $\beta$-karoten, aktivitas antioksidan dan sensori (warna, tekstur, rasa, daya oles, overall pada sampel dengan penambahan puree wortel) dan penurunan terhadap kadar lemak dan sensori (warna, tekstur, rasa, daya oles, overall pada sampel dengan penambahan ekstrak wortel).
3. Karakteristik Chili Cream Cheese dengan penambahan ekstrak wortel terpilih adalah dari penambahan ekstrak wortel $7 \%$ dengan rendemen $6,36 \pm 0,380 \%$; nilai $\mathrm{pH}$

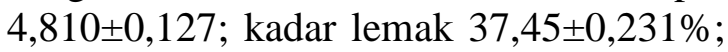
kadar betakaroten $201,32 \pm 4,399 \mu \mathrm{g} / \mathrm{gram}$ sampel; aktivitas antioksidan $2,20 \pm 0,074 \%$ penangkapan radikal $\mathrm{dpph} / \mathrm{mg}$ sampel dengan aroma, warna, tekstur, rasa, aftertaste, daya oles dan overall rata-rata "sama dengan kontrol". Karakteristik Chili Cream Cheese dengan penamabahan puree wortel terpilih adalah dari penambahan puree wortel $21 \%$ dengan nilai rendemen $7,19 \pm 0,433 \%$; nilai $\mathrm{pH} 4,803 \pm 0,222$; kadar lemak $30,86 \pm 0,210 \%$; kadar betakaroten $244,97 \pm 6,728 \mu \mathrm{g} / \mathrm{gram}$ sampel; aktivitas antioksidan $4,32 \pm 0,075 \%$ penangkapan radikal dpph/mg sampeldengan aroma, warna, tekstur, rasa, aftertaste, daya oles dan overall rata-rata "sama dengan kontrol"

\section{DAFTAR PUSTAKA}

[FAO] Food and Agriculture Organization, (2005). Manual Methods of Analysis of Foods (Milk and Milk Products).Directorate General of Health Services Ministry of Health and Family Welfare Government of India. New Delhi.

AOAC.(1970). Official Methods of Analysis.Association of Official of Analytical Chemist. Washington D.C.

Asgar A. dan Musaddad D. (2006). Optimalisasi Cara, Suhu dan Lama Blansing sebelum Pengeringan pada Wortel. J. Hort 16(3):245-252. Balai Penelitian Tanaman Sayuran. Bandung.

Bauernfeind JC, Klaul H. (1981). Carotenes as Colorans and Vitamin A Precursore. Florida:Academic Press.

CODEX STAN 275. (1972). Codex International InduvidualStandard for Cream Cheese. Codex Allimentarius.

Dalimartha S dan Soedibyo M. (1998). Awet Muda dengan Tumbuhan Obat dan Diet Suplemen. Trubus Agriwidya. Jakarta. 
deMan, J.M. (1997). Kimia Makanan. Penerbit ITB. Bandung.

Elenbogen, G. D., Skokie, Baron, M. (1968).Imitation Cream Cheese Spread Containing PUFA.Illnois. Chicago.

Gandhi, D. N. (2006).Food and Industrial Microbiology: Microbiology of Fermented Dairy Products. Principal Scientist Dairy Microbiology Division National Dairy Research Institute, Karnal.

Kartika, B. P. Hastutidan W. Supartono. (1988). Pedoman Uji Inderawi Bahan Pangan.Pusat Antar Universitas Pangan dan Gizi Universitas Gadjah Mada, Yogyakarta.

Little, L.L dan Coeur, C. (1967).Process of Making Sour Cream Type Products and Cream Cheese.US Patent Office.

Lucey, J.A. (2003). Acid and Acid/Heat Coagulated Cheese, in Encyclopedia of Dairy Sciences, Vol.1 (ed. H. Roginski, J.W. Fuquay, and P.F. Fox), Academic Press, London, pp. 350-356.

Mulyani, S., Azizah, A., Legowo, A.M. (2009).Profil Kolesterol, Kadar Protein dan Tekstur Keju Menggunakan Mucor Miehei sebagai Sumber Koagulan. Skripsi Jurusan Teknologi Hasil Ternak, Fakultas Peternakan, Universitas Diponegoro.

Mutiara,

D.

A.

(2000).PengaruhJenisdanKonsentrasiBah anPenstabilpada Velva Nanas (AnanasComolus L. Merr.).Skripsi Jurusan Teknologi Pangan dan Gizi, Fakultas Teknologi Pertanian, Institut Pertanian Bogor.

Ningtias, P. A. danNugraha G. I. (2008).Pengaruh Pemberian Betakaroten dalam Wortel Kukus ( Daucus carota L.) terhadap Malonaldehide Plasma pada Subjek yang Terpapar Polusi Gas Buang Kendaraan Bermotor di Alun-alun Kota Bandung. ITB. Bandung.

Setyaningsih D., Apriyantono A., dan Sari, M.P. (2010). Analisis Sensori untuk Industri Pangan dan Agro. IPB Press, Bogor.
Silalahi, J.(2006). Makanan Fungsional. Yogyakarta. Penerbit Kanisius.

Spreer, E. (1998). Milk and Dairy Product Technology. Mercel Dekker Inc. New York.

Subagioet al., (2002).Characterization of Hyacinth Bean Seeds from Indonesia and Their Protein Isolate. Journal Food Chemistry Vol 95, 65-70.

Suraningsih. (2000). Pengaruh Jenis dan Konsentrasi Bahan Penstabil terhadap Mutu Velva Sirsak (Annona muricata Lin). Jurusan Teknologi Pangan dan Gizi, Fakultas Teknologi Pertanian. IPB.

USDA.(1994). USDA Specifications for Cream Cheese, Cream Cheese with Other Foods, and Related Products.Dairy Division.Agricultural Marketing Service.United States Department of Agriculture.

Winarno, F. G. (1991). Kimia Pangan dan Gizi. PT Gramedia Pustaka Utama. Jakarta.

Zubaidah, E., Saparianti, E., Mawardhani, M. (2005).Peranan Substitusi dengan Sari Wortel dan Kondisi Fermentasi terhadap Karakteristik Minuman Susu Terfermentasi Bakteri Asam Laktat. Jurnal Teknologi Pertanian, Vol. 6 No.2 hal. 93100. Unibraw. Malang. 